\title{
THE EFFECT OF WATER STRESS ON NITROGEN STATUS AS WELL AS WATER USE EFFICIENCY OF POTATO CROP UNDER DRIP IRRIGATION SYSTEM
}

\author{
Abd El-Mageed, H. N. ${ }^{1}$, M. M. Ibrahim ${ }^{2}$, A. M. Elbeltagi ${ }^{3}$
}

\begin{abstract}
Water and nitrogen management, rate and timing of application are critical factors in optimizing potato tuber yield and quality. This study was conducted to determine the effect of water stress and nitrogen fertilizer levels on canopy water content (CWC), soil water content $(S W C)$, nitrogen uptake, SPAD values, water use efficiency (WUE) and potato yield. Water treatments concluded fully irrigated and water stress. While, nitrogen levels were (N0, N50 and N100). Surface drip irrigation system was used to provide irrigation water requirements. Treatments were irrigated when $35 \%$ of available soil moisture was consumed in soil profile depth. For nitrogen levels (N0, N50 and N100) at water stress conditions, the percentage of irrigation water saved was $11.47 \%$ led to decrease the tuber yield with $31 \%, 13.94 \%$ and $25.25 \%$, respectively. SPAD values were highest in water stress and lowest in the control. In addition, SPAD values were in a positive linear relationships with water and nitrogen treatments as a coefficient of determination with very high $\left(R^{2}=0.99\right.$ and 0.99), respectively. Also, increasing the nitrogen dose led to the increase the nitrogen uptake values. Moreover, nitrogen uptake presented a linear relationships with water regimes at nitrogen levels (0.96 and 0.97), respectively. Also, SPAD values presented linear relationships with nitrogen uptake at well water controlled, stressed and nitrogen levels $\left(R^{2}=0.99\right.$ and 0.99). In conclusions, there were obvious effects of water stress on CWC, SWC, nitrogen uptake and WUE. On the other hand, canopy water content and soil water content could be used to predict potato WUE and yield.
\end{abstract}

Keywords: Water stress, Canopy water content, Nitrogen uptake, SPAD value, Water use efficiency.

\footnotetext{
${ }^{1}$ and $^{2}$ Prof. and Assoc. Prof of Agric. Eng., Faculty of Agric., Al-Mansoura Univ.

${ }^{3}$ Demonstrator of Agric. Eng. Dept., Faculty of Agric., Al-Mansoura Univ.
} 


\section{INTRODUCTION}

$\mathrm{P}$ otato is one of the most important irrigated crops as they are sensitive to soil moisture deficit. The cultivated area of potato in Egypt was about 164141 hectares in 2011 with productivity about433843 ton (Faostat, 2011). Nitrogen $(N)$ is an essential element in plant growth and productivity, and $\mathrm{N}$ fertilizer is therefore of prime importance in cultivated crops. The amount and timing of $\mathrm{N}$ application has economic and environmental implications and is consequently considered to be an important issue in precision agriculture (Johnson 2001). According to that, Demotes et al. (2008) stated that chlorophyll is the most important pigment in leaves, and it is responsible of their greenness. Leaf chlorophyll content can be used as a nitrogen status indicator because this is an essential element in the photosynthetic protein synthesis. Gianquinto et al. (2004) found that SPAD values are also positively correlated with both specific leaf weight and maximum photosynthesis rate. Al-Mahmud et al. (2014) studied the effect of severe stress, moderate stress and well watered conditions on SPAD values. They found values of SPAD meter values varied from 45.86 to 53.60 , from 35.43 to 48.06 and from 37.66 to 45.90 , respectively. The mean values of chlorophyll content of potato leaves varied from 55 to 58 and from 49 to 60 with SPAD unit under well watered condition in several stages of growth (Isabella et al., 2012). Water stress affects the development and growth of potato shoots, roots and tuber yield. Water stress also induces reducing leaf area and in the long term stem height and ground coverage was lower. Reducing water application and increase available nitrogen led to a decrease in Specific gravity generally (Ojala et al. 1990). Occurring water stress at any time during the growing season reduces potato marketable, total tuber yield, tuber length and diameter and quality (Bailey, 1990). Similar to that, all growing stages of potato especially tuber formation stage is very sensitive to water stress (Shock, 2004). Water stress was greater at tuber initiation (40\%) than tuber development stage (30\%) with reduction in tuber yield by $23 \%$ Kumar and Minhas (1999). Otherwise, Ibrahim et al. (2015) found that the best scheduler model was CROPWAT for irrgation water management under Egyptian conditions at evaluation three models 
(CROPWAT, CAMISM and IRRIS) for corn and wheat crops. Also, Kassem et al. (2005) studied the effect of water regimes at five different levels of soil moisture content $(15,30,45,60$, and $75 \%)$ of soil moisture depletion on potato yield. The results showed that the total yield were $(20.8,16.4,13.88,11.42$ and 9.69) ton/ha, respectively. Tuber yield were 28.85, 24.48, and 19.7 ton/ha at irrigation levels $100 \%, 60 \%$ and 30\%, respectively (EL Mokh et al., 2014). Moreover, the yield increased with the use of up to $100-150 \mathrm{~kg} \mathrm{~N} / \mathrm{ha}$ and dry matter content was significantly diminished by the amount of nitrogen up to $150 \mathrm{~kg} \mathrm{~N} / \mathrm{ha}$ (Beirne and Cassidy, 1990). Also at levels 0, 60, 120 and $180 \mathrm{~kg} \mathrm{~N} / \mathrm{ha}$, Tuber yield was increased with increasing nitrogen fertilization levels (Juzl, 1993). But the effect irrigation water and nitrogen levels on potato yield indicated by (El Mokh et al., 2015), who studied the effect of water regimes with levels of $100 \%, 60 \%$ and $30 \%$ with nitrogen treatments N0, $\mathrm{N} 100, \mathrm{~N} 200$, and N300 kg/ha on yield. The potato yield were (13.15, 11.39 and 7.42) ton/ha for three levels of irrigation at N0, respectively. For N50, N100 and N200 at three irrigation levels, tuber yield were $(15.07,12.05$ and 8.53$)$ ton/ha, $(18.89,14.78$ and 9.68) ton/ha and (22.72, 15.94 and 9.24$)$ ton/ha, respectively.

\section{The main objective of this study was to:}

(1) determine the effect of water regimes on soil water content (\%), canopy water content (\%), water use efficiency and yield of potato crop.

(2) determine the effect of water regimes on dry matter $(\mathrm{kg} / \mathrm{fed})$, nitrogen uptake and SPAD value.

(3) determine the relationship between SPAD value and nitrogen uptake ( $\mathrm{kg} / \mathrm{fed})$.

\section{MATERIAL AND METHODS}

\subsection{Study Area}

Field experiments were conducted during the period from 2015 to 2016 on two seasons at the research station of the Sadat City University in Egypt $\left(30^{\circ} 2^{\prime} 41.185^{\prime \prime} \mathrm{N}\right.$ and $\left.31^{\circ} 14^{\prime} 8.1625^{\prime \prime} \mathrm{E}\right)$. The research station of the Sadat City University is characterized as a semi-arid climate with moderate cold winter sand warm summers. The type of tuber potato was 
spunta for the two seasons. First season planted on 13th of October 2015 and harvested on February 9, 2016. While, the second season planted on February 1, 2016 and harvested on May 31, 2016. Chemical and mechanical analysis of soil for experimental site are presented in Table (1). The experimental soil was sandy loam in texture. maximum rain infiltration rate was $30 \mathrm{~mm} /$ day and electrical conductivity of irrigation water was $0.62 \mathrm{ds} / \mathrm{m}$.

Table (1): Chemical and mechanical analysis of soil for the experimental site.

\begin{tabular}{|ll|ll|lll|}
\hline \multicolumn{6}{|c|}{ Chemical and mechanical analysis of soil } \\
\hline PH & 8.21 & WP & $80 \mathrm{~mm} / \mathrm{m}$ & Sand $(\%)$ & 69.8 \\
N & 101.5 & BD & $1.45 \mathrm{~g} / \mathrm{cm}^{3}$ & Silt $(\%)$ & 22.3 \\
P & 4.47 & EC & $0.95 \mathrm{ds} / \mathrm{m}$ & Clay $(\%)$ & 7.9 \\
K & 244.9 & OM & $0.36 \%$ & & & \\
FC & $192 \mathrm{~mm} / \mathrm{m}$ & CC & $5 \%$ & & & \\
\hline
\end{tabular}

$\mathrm{BD}=$ bulk density, $\mathrm{OM}=$ organic matter, $\mathrm{CC}=$ calcuim carbonate content

\subsection{Experimental Layout}

As mentioned before the surface drip irrigation system has been used in this study. As shown in Figure (1), the experimental design divided into four replicates (R1, R2, R3 and R4) with 24 plots. Each plot was $3 \times 3 \mathrm{~m}^{2}$ that consists of three rows. Spaces between rows were $70 \mathrm{~cm}$ and spaces between tubers were $30 \mathrm{~cm}$. A two factor split- plot design experiment was used with four randomized blocks as replicates. Each replicate consists of two treatments of irrigation with three levels of nitrogen fertilizer application. Water treatments were fully irrigated and water stressed. Three levels of nitrogen $(\mathrm{N})$ were $0 \mathrm{~kg} / \mathrm{fed}(\mathrm{N} 0), 90 \mathrm{~kg} / \mathrm{fed}$ (N90), and $180 \mathrm{~kg} / \mathrm{fed}$ (N180). The nitrogen fertilizer was added after 21, 60 days from planting date as ammonium nitrate (NH4NO3 33.5\%). The recommended doses from super phosphate and potassium sulphate at a rate of 75 and $96 \mathrm{~kg} / \mathrm{fed}$, respectively were added in initial and mid stages. In this study, $4 \mathrm{l} / \mathrm{h}$ discharge were used to control the flow of water from the lateral to the potato plants. Diameter of mainline and lateral was 50,16 mm, respectively. The experimental area consists of twelve lines. Each line was 18 meters in length. Valves were installed at the first of each line to manage irrigation time. Water stress periods were 
conducted at tuber bulking stage for two seasons. Water stress for first season was from 24 December 2015 to 10 January 2016. While for second season, water stress was from 27 April 2016 to 7 May 2016، respectively.

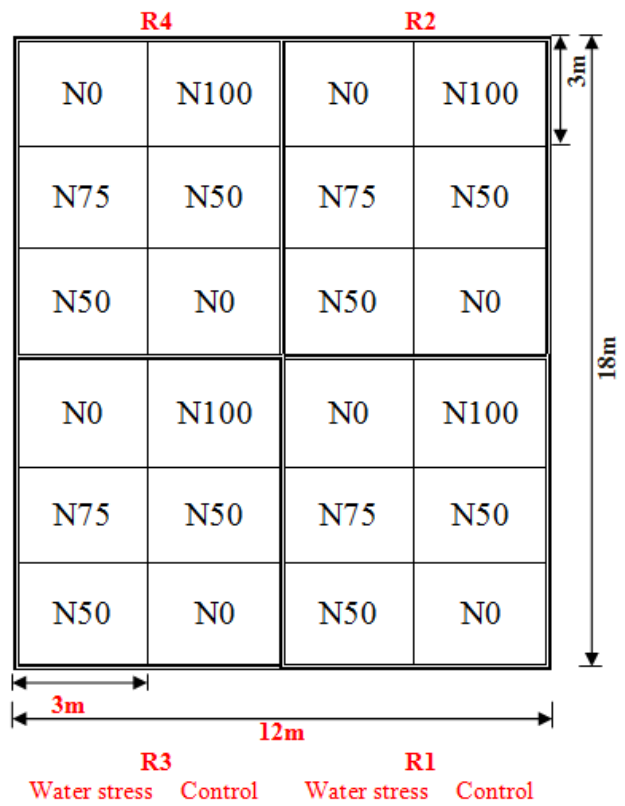

Fig. (1): The layout of experimental design for control, water stress and three levels of nitrogen fertilizer.

\subsection{Irrigation Water Requirements}

In this study, FAO CROPWAT software ver. 8.0 developed by Smith, (1992) was used to decide when to irrigate and how much water to be applied to experimental replicates. FAO Penman-Monteith method used by this software as the standard method for the computation of the reference evapotranspiration. This method is preferred where data of temperature, humidity, wind speed, sunshine duration are available. The weather data for experimental site were obtained from (World weather online, 2015). Rainfall amounts during two seasons were collected and measured using rainfall collector stalled in the experimental site. The weather data were used in daily basis. FAO Penman-Monteith equation was used to calculate Eto according to (Allen et al., 1998). 


$$
E T o=\frac{0.408 \Delta(R n-G)+\gamma \frac{900}{T+273} u_{2}(e s-e a)}{\Delta+\gamma\left(1+0.34 u_{2}\right)} \ldots \ldots
$$

Where; $\quad$ Eto $=$ reference evapotranspiration, $\left(\mathrm{mm} \mathrm{day}^{-1}\right), \quad \mathrm{R}_{\mathrm{n}}=$ net radiation at the crop surface, $\left(\mathrm{MJ} \mathrm{m}^{-2} \mathrm{day}^{-1}\right), \mathrm{G}=$ soil heat flux density, (MJ $\mathrm{m}^{-2}$ day $\left.^{-1}\right), \mathrm{T}=$ air temperature at $2 \mathrm{~m}$ height, $\left({ }^{\circ} \mathrm{C}\right), \mathrm{u}_{2}=$ wind speed at $2 \mathrm{~m}$ height, $\left(\mathrm{m} \mathrm{s}^{-1}\right), \mathrm{e}_{\mathrm{s}}=$ saturation vapour pressure, $(\mathrm{kPa}), \mathrm{e}_{\mathrm{a}}=$ actual vapour pressure, $(\mathrm{kPa}), \mathrm{e}_{\mathrm{s}}-\mathrm{e}_{\mathrm{a}}=$ saturation vapour pressure deficit, $(\mathrm{kPa}), \Delta=$ slope vapour pressure curve, $\left(\mathrm{kPa}{ }^{\circ} \mathrm{C}^{-1}\right)$, and $\gamma=$ psychrometric constant, $\left(\mathrm{kPa}{ }^{\circ} \mathrm{C}^{-1}\right)$.

\subsection{Field Measurements}

\subsubsection{Chlorophyll meter}

The Soil-Plant Analysis Development (SPAD) unit of Minolta Camera Company has developed the SPAD-502 chlorophyll meter. As shown in Figure (2), it determines the chlorophyll concentration by measuring the leaf absorbance in red and near-infrared regions. The light is emitted by two leds with peak wavelengths at $650 \mathrm{~nm}$ and $940 \mathrm{~nm}$. The accuracy of the SPAD-502 is \pm 1.0 units. The measuring area is $2 \mathrm{~mm} \times 3 \mathrm{~mm}$. This numerical SPAD value specifies the relative content of chlorophyll within the sample leaf (Konica Minolta Optics, 2012). In this study, Average values of three leaves per each plant in plot were measured to determine the chlorophyll content. Measurements were taken throughout water stress periods for the control and water stress plots.

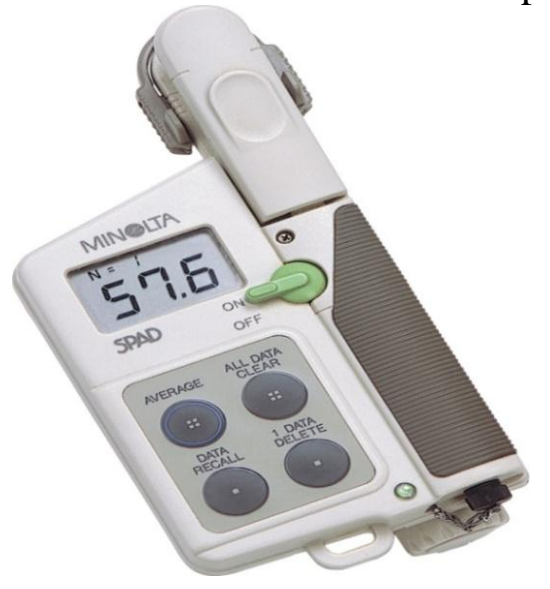

Fig. (2): Portable chlorophyll meter SPAD-502 for measuring chlorophyll in potato crop. 


\subsubsection{Soil water content (SWC)}

In this study, gravimetric dry weight basis method was used for measuring the moisture level of experimental soil. The gravimetric water content is the mass of water per mass of dry soil. Soil water content measured in the laboratory by weighing soil samples before and after drying.The samples were dried in an oven at $105{ }^{\circ} \mathrm{C}$ for 24 hours. Soil water content was determined using following equation:

$$
\mathrm{SWC}(\%)=\frac{\text { Mwater }}{\text { Mdry }}=\frac{(\text { Mwet }- \text { Mdry })}{\text { Mdry } \ldots . . .(2)}
$$

Where; Mwater $=$ mass of water, and Mdry = mass of dry soil.

\subsection{Measurements on Potato Plants}

\subsubsection{Potato canopy water content}

Potato plants Arial biomass was cut above the ground for all studying plots. Thereafter, a representative subsample was placed in an oven at 70 ${ }^{0} \mathrm{C}$ for 24 hours. Samples were weighted before and after drying to determine canopy water content. The percentage canopy water content was calculated using following equation:

$$
\mathrm{CWC}=\frac{F W-D W}{F W} \times 100 .
$$

Where; FW = fresh weight, and DW= dry weight.

\subsubsection{Water use efficiency and yield of potato}

To determine the potato yield, three plants per each plot were harvested. While, water use efficiency (WUE) is defined as the yield obtained per unit of water consumed. An irrigation of $70 \mathrm{~mm}$ was applied before planting and not included in the total. Water use efficiency (WUE) was calculated according to (Akhter, 2017) using the following equation:

$$
\mathrm{WUE}=\mathrm{Y} / \mathrm{WR}
$$

Where; $\mathrm{Y}=$ yield $(\mathrm{kg} / \mathrm{fed})$

$\mathrm{WR}=$ the total amount of water applied in the field $\left(\mathrm{m}^{3} / \mathrm{fed}\right)$

\subsubsection{Determination of nitrogen uptake}

Average three samples from each plot was oven dried to estimate the dry matter and nitrogen content at irrigated and water stress treatments. 
These samples were analyzed at the laboratory of soil fertility tests and fertilizers quality control, Faculty of agriculture, AL-Mansoura University. In Figure (3), the thermo scientific FLASH 2000 series analyzer was used to estimate the total nitrogen content in all samples. This instrument operates according to the dynamic flash combustion modified Dumas method of the sample for the determination of carbon, nitrogen and sulfur. Samples are weighed in a tin capsule and introduced into the combustion reactor by an auto sampler.

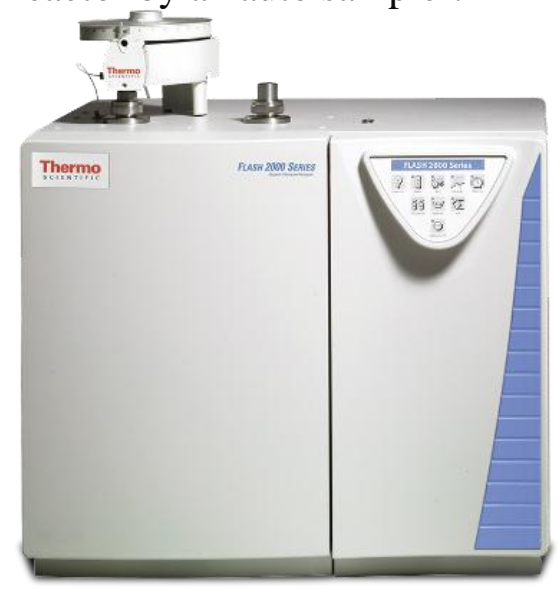

Fig. (3): Thermo Scientific FLASH 2000Series Analyzer

The nitrogen uptake was calculated according to (Lemaire and Gastal, 1997) using the following equation.

$$
\mathrm{N} \text { uptake }=\mathrm{W} \times \mathrm{N}_{\text {act }}
$$

Where; $\mathrm{W}=$ dry matter of sample, $\left(\right.$ ton/fed), and $\mathrm{N}_{\text {act }}=$ actual measured $\mathrm{N}$ content in percent of the dry matter of the canopy (\%).

\subsection{Statistical Analysis}

SPSS 19 for Windows version 10 (SPSS Inc., Chicago, IL) was used for the statistical analysis. Simple regressions were calculated to analyze the relationship between canopy water content, soil water content, dry biomass, nitrogen uptake and water productivity. In addition, the relationship between SPAD value, nitrogen uptake and yield was estimated. Coefficients of determination $\left(\mathrm{R}^{2}\right)$ and significance test were determined. A nominal alpha value of 0.05 was used. 


\section{RESULTS AND DISCUSSION}

\subsection{Climate Factors and Irrigation Water Requirements for the Two}

\section{Seasons}

In this study, Figure (4) shows average monthly of climate factors (minimum and maximum temperature $\left({ }^{\circ} \mathrm{c}\right)$, humidity (\%), wind speed $(\mathrm{km} /$ day) and rainfall amounts $(\mathrm{mm})$ during the growing seasons. Rainfall amounts were 34.8, $4.8 \mathrm{~mm}$ for first and second season, respectively. Irrigation scheduling for two seasons are shown in Figures $(4,5)$. As suggested by CROPWAT program, potato crop for first season require 24 irrigations totaling $167.1 \mathrm{~mm}$ divided in average over two or three days intervals at most and water stress at late stage for first season was $20.9 \mathrm{~mm}$. While for second season, the gross irrigation was 497.6 $\mathrm{mm}$ with 61 irrigations divided in average over one or two days intervals at most and water stress at late stage for second season was $63.3 \mathrm{~mm}$.

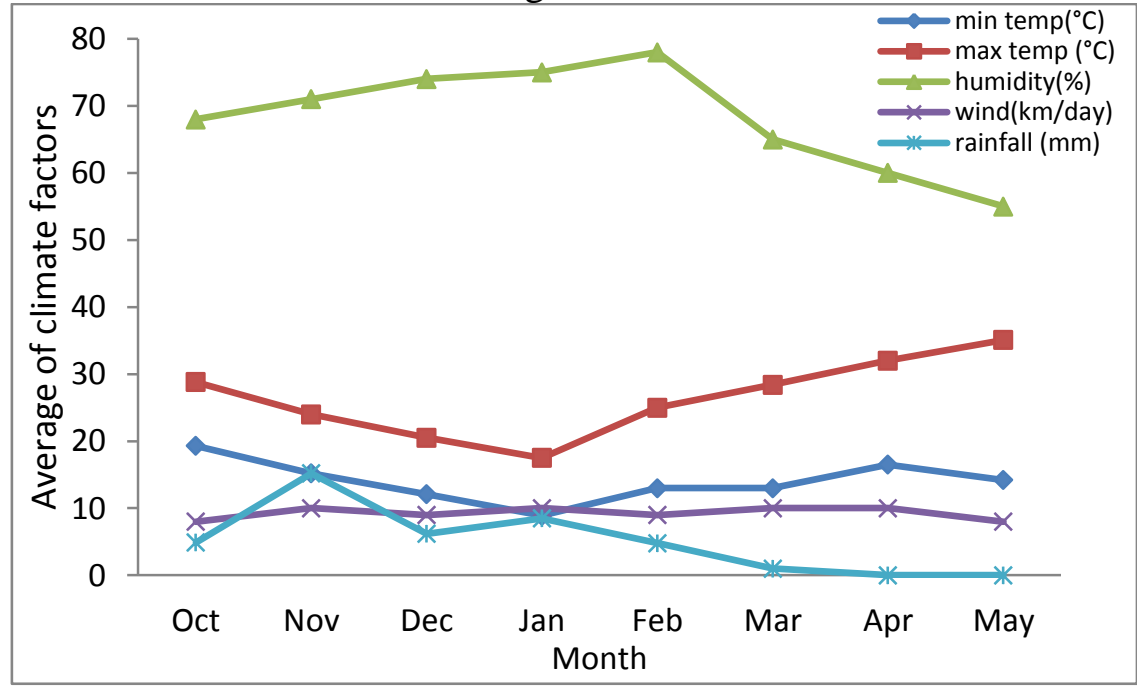

Fig.(4): Average monthly of climate factors (temperature ${ }^{\circ} \mathrm{c}$, humidity $\%$, wind speed $\mathrm{km} /$ day and rainfall amounts, $\mathrm{mm}$ ) for two seasons.

\subsection{The Effect of Water Regimes Levels on Soil Water Content, Canopy Water Content, Water Use Efficiency and Yield of Potato Crop}

In Table (2), maximum, minimum, mean values and standard deviation of SWC (\%), CWC (\%), WUE $\left(\mathrm{kg} / \mathrm{m}^{3}\right)$ and yield (ton/fed) were demonstrated at control and water stress conditions, respectively. In 
general, it could be concluded that the control treatments always gives higher values for SWC (\%), CWC (\%), WUE $\left(\mathrm{kg} / \mathrm{m}^{3}\right)$ and yield (ton/fed) than the obtained under the stressed conditions as shown in Figures (7 and 8). Results for two seasons show the mean values of SWC for control conditions and water stress conditions. It varied from $11.53 \%$ to $11.73 \%$ under control conditions.

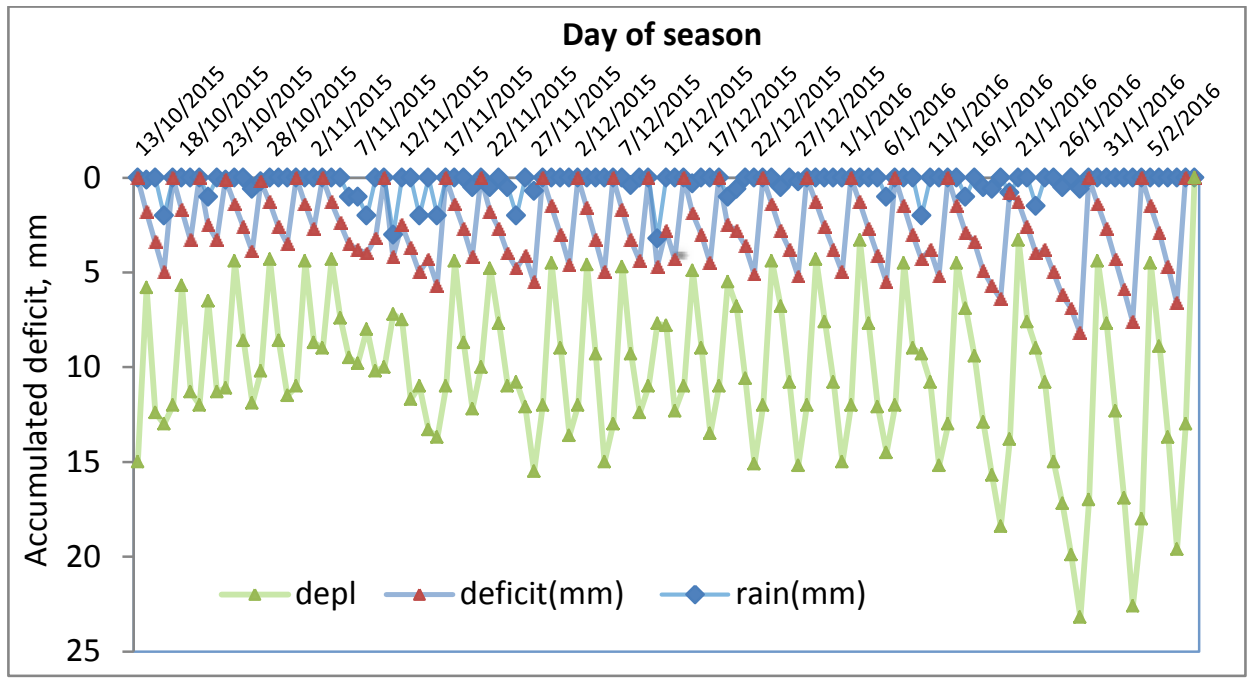

Fig. (5): Potato crop irrigation scheduling for first season.

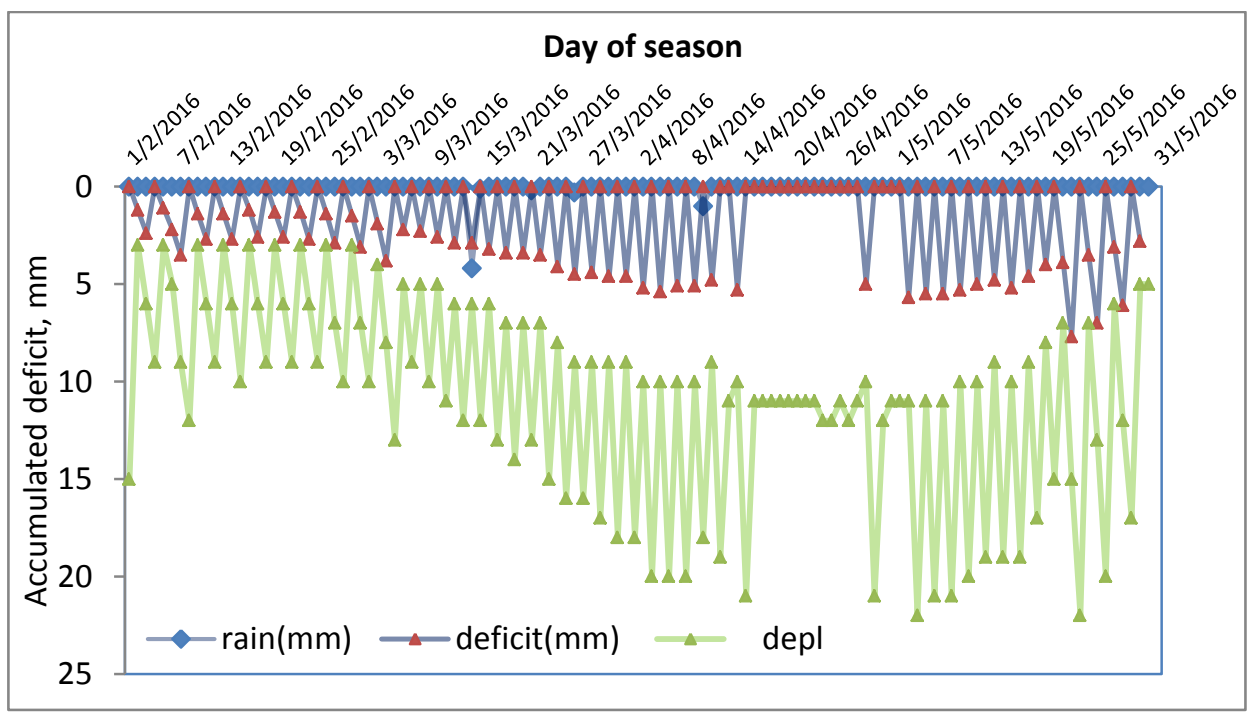

Fig. (6): Potato crop irrigation scheduling for second season. 
Table (2): Average soil water content (\%), canopy water content (\%), water use efficency $\left(\mathrm{kg} / \mathrm{m}^{3}\right)$, and yield (ton/fed) value under control and water stress conditions at three nitrogen levels for two seasons.

\begin{tabular}{|c|c|c|c|c|c|c|c|c|c|}
\hline \multirow{2}{*}{$\begin{array}{l}\text { Measured } \\
\text { parameters }\end{array}$} & \multirow{2}{*}{ Treatments } & \multicolumn{4}{|c|}{ First season } & \multicolumn{4}{|c|}{ Second season } \\
\hline & & Min & Max & Mean & SD & Min & Max & Mean & SD \\
\hline \multirow{6}{*}{ SWC (\%) } & N0-C & 11.9 & 12.42 & $10.63 \mathrm{a}$ & 0.82 & 11.25 & 11.77 & $11.51 \mathrm{a}$ & 0.04 \\
\hline & N50-C & 12.6 & 13.4 & $12.06 \mathrm{a}$ & 1.16 & 12.4 & 12.66 & $12.5 \mathrm{a}$ & 0.00 \\
\hline & N100-C & 11.7 & 11.96 & $11.9 \mathrm{a}$ & 0.50 & 11.15 & 11.3 & $11.2 \mathrm{a}$ & 1.07 \\
\hline & No-WS & 6.22 & 7.68 & $8.97 \mathrm{~b}$ & 0.38 & 7.7 & 7.82 & $7.79 b$ & 0.08 \\
\hline & N50-WS & 6.96 & 8.05 & $7.63 \mathrm{~b}$ & 0.47 & 7.86 & 8.12 & $8.08 \mathrm{~b}$ & 0.04 \\
\hline & N100- WS & 7.7 & 8.51 & $8.40 \mathrm{a}$ & 2.31 & 7.9 & 8.51 & $8.11 \mathrm{~b}$ & 0.57 \\
\hline \multirow{6}{*}{ CWC (\%) } & N0-C & 85.00 & 91.56 & $89.03 \mathrm{a}$ & 0.76 & 84.94 & 86.87 & $85.11 \mathrm{a}$ & 0.24 \\
\hline & N50-C & 85.03 & 89.42 & $87.95 \mathrm{a}$ & 2.53 & 82.57 & 87.04 & $86.1 \mathrm{a}$ & 0.00 \\
\hline & N100-C & 87.13 & 88.18 & $87.64 \mathrm{a}$ & 0.46 & 81.35 & 88.02 & $86.75 a$ & 0.23 \\
\hline & No-WS & 79.17 & 81.32 & $79.89 \mathrm{~b}$ & 1.23 & 81.25 & 83.64 & $82.25 b$ & 0.00 \\
\hline & N50-WS & 81.89 & 84.32 & $82.76 \mathrm{~b}$ & 1.05 & 79.99 & 83.21 & $81.71 \mathrm{~b}$ & 2.11 \\
\hline & N100-WS & 79.64 & 84.67 & $81.44 \mathrm{~b}$ & 2.79 & 79.61 & 82.00 & $80.80 \mathrm{~b}$ & 1.60 \\
\hline \multirow{6}{*}{$\begin{array}{l}\text { WUE } \\
\left(\mathbf{k g} / \mathbf{m}^{3}\right)\end{array}$} & No-C & 5.87 & 7.92 & $7.68 \mathrm{~d}$ & 1.73 & 2.36 & 2.80 & $2.77 \mathrm{~cd}$ & 0.00 \\
\hline & N50-C & 8.48 & 10.79 & $10.52 \mathrm{ab}$ & 2.92 & 2.67 & 4.59 & $3.47 \mathrm{ab}$ & 2.17 \\
\hline & N100-C & 11.82 & 13.30 & $13.28 \mathrm{a}$ & 1.59 & 4.28 & 5.34 & $5.20 \mathrm{a}$ & 1.32 \\
\hline & No-WS & 3.47 & 6.30 & $5.02 \mathrm{~cd}$ & 3.66 & 1.90 & 3.06 & $2.01 \mathrm{~d}$ & 2.61 \\
\hline & N50-WS & 5.84 & 9.67 & $8.57 \mathrm{bcd}$ & 2.90 & 3.11 & 3.20 & $3.15 \mathrm{~cd}$ & 1.69 \\
\hline & N100- WS & 9.33 & 9.38 & $9.35 \mathrm{abc}$ & 0.03 & 3.15 & 4.68 & $4.12 b c$ & 2.00 \\
\hline \multirow{6}{*}{$\begin{array}{c}\text { Yield } \\
\text { (ton/fed) }\end{array}$} & N0-C & 4.98 & 6.71 & $5.84 c$ & 1.22 & 4.98 & 5.90 & $5.11 \mathrm{~d}$ & 0.00 \\
\hline & N50-C & 7.20 & 9.15 & 8.0ab & 0.11 & 5.60 & 6.69 & 6.40ab & 1.51 \\
\hline & N100-C & 10.03 & 10.40 & $10.11 \mathrm{a}$ & 1.12 & 9.04 & 11.28 & $9.60 \mathrm{a}$ & 0.92 \\
\hline & N0-WS & 2.64 & 4.79 & $3.82 \mathrm{c}$ & 2.56 & 3.50 & 5.64 & $3.71 \mathrm{~d}$ & 1.82 \\
\hline & N50-WS & 4.44 & 7.35 & $6.52 \mathrm{bc}$ & 2.05 & 5.73 & 5.89 & $5.80 \mathrm{~cd}$ & 1.19 \\
\hline & N100- WS & 7.09 & 7.13 & 7.11ab & 1.06 & 5.83 & 8.63 & $7.6 \mathrm{bc}$ & 0.87 \\
\hline
\end{tabular}

$\mathrm{CWC}=$ canopy water content, $\mathrm{SWC}=$ soil water content, $\mathrm{WUE}=$ water use efficency.

The slope was (0.74) and coefficient of determination was (0.88). Under water stress conditions, it varied from $6.22 \%$ to $8.97 \%$ and the coefficient of determination was (0.98) with slope (0.455). Moreover, CWC at three nitrogen levels ranged from $85 \%$ to $91.56 \%$ for first season and from $81.35 \%$ to $88.02 \%$ for second season under control conditions with slope $(0.82)$ and $\left(\mathrm{R}^{2}=0.99\right)$, respectively. While in water stress treatments, CWC varied from $79.17 \%$ to $84.67 \%$ for first season and from $79.61 \%$ to $83.64 \%$ for second season with slope $(0.87)$ and $\left(\mathrm{R}^{2}\right.$ $=0.87$ ), respectively. In Figure (8), Results of WUE were 7.68 to 13.28 $\mathrm{kg} / \mathrm{m}^{3}$ and 5.02 to $9.35 \mathrm{~kg} / \mathrm{m}^{3}$ for the first season under controlled and stressed conditions. As well as for the second season, these values were 2.77 to $5.20 \mathrm{~kg} / \mathrm{m}^{3}$ and 2.01 to $4.12\left(\mathrm{~kg} / \mathrm{m}^{3}\right)$ for controlled and stressed conditions, respectively. The coefficient of determination was (0.94) and 
the slope was (1.215) for the control. In addition in water stressed, the coefficient of determination was (0.94) and the slope was (1.61). These results are in agreement with Juzl (1993); Kassem et al. (2005). Also, it agreed with Onder et al. (2005) who found that water stress significantly affected potato yield and yield parameters at irrigation levels 0, 33, 66 and 100 of fully irrigated.

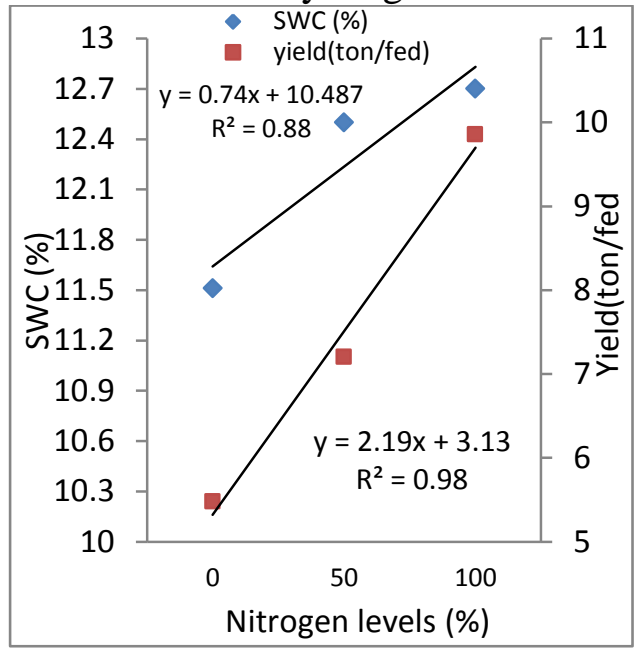

(a)

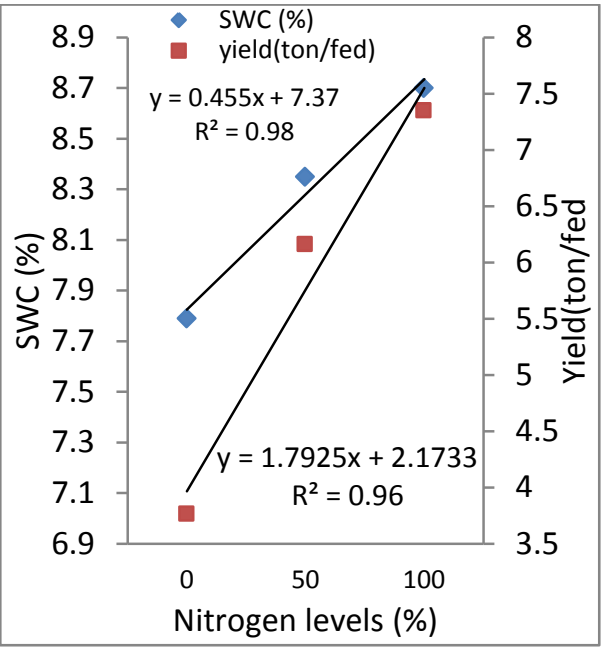

(b)

Fig.(7) The effect of water regimes levels on soil water content and potato yield: (a) control and (b) water stress conditions.

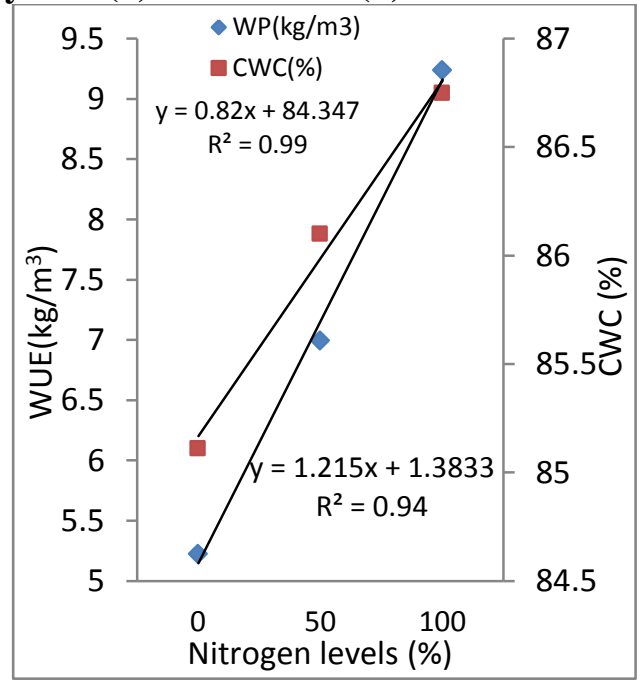

( a)

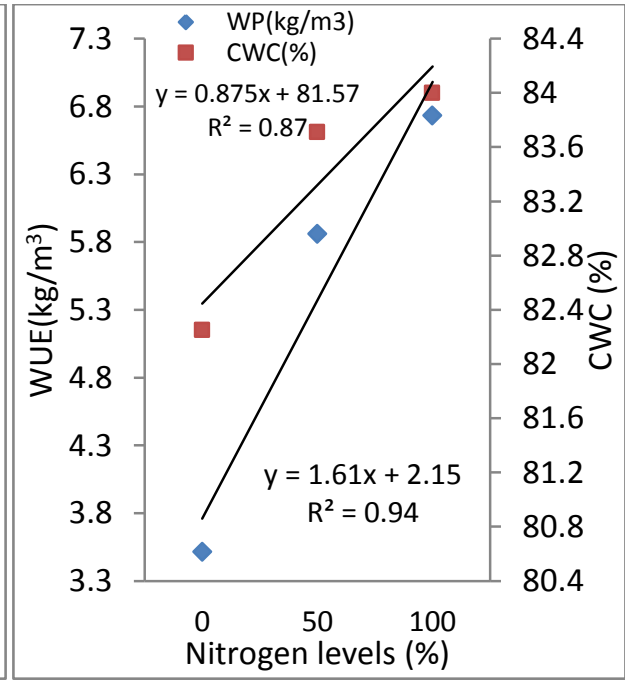

(b)

Fig.(8) The effect of water regimes levels on canopy water content and water use efficency: (a) control and (b) water stress conditions. 


\subsection{The Effect of Water Regimes Levels on Dry Matter, Nitrogen Concentration, Nitrogen Uptake and SPAD Values of Potato Crop}

The effect of water regimes on dry biomass $(\mathrm{kg} / \mathrm{fed})$, nitrogen uptake ( $\mathrm{kg} / \mathrm{fed})$ and SPAD values have been determined. These results have been recorded as the average of three values per each plot. They were measured at three nitrogen levels under control and water stress treatments for two seasons as presented in Table (3). Results show that the nitrogen concentration generally increased with increasing water stress. For the first season, the mean nitrogen concentration values were $2.9 \%, 3.3 \%$ and $3.7 \%$ for control conditions and other three nitrogen levels (N0, N50 and N100), respectively. For the second season, the previous values were $2.8 \%, 3.0 \%$ and $3.6 \%$, respectively. At water stress conditions, the nitrogen concentration increased to $3.1 \%, 3.6 \%$ and $3.9 \%$ for first season and $3 \%, 3.5 \%$ and $4.1 \%$ for second season, respectively. Increasing the nitrogen dose from N0 - N50 and N100 led to increase the nitrogen uptake to become $7.7,14.36$ and $18.37 \mathrm{~kg} / \mathrm{fed}$ at at zero water stress level for first season. The corresponding values at water stress were $6.21,11.74$ and $16.79 \mathrm{~kg} / \mathrm{fed}$. For the second season, the nitrogen uptake became $25.5,40.98$ and $81.9 \mathrm{~kg} / \mathrm{fed}$ at zero stress level, and 22.81, 38.65 and $71.28 \mathrm{~kg} / \mathrm{fed}$ at water stress conditions, respectively. These results coincide with Costa et al. (1997) who reported that nitrogen uptake values were $21.5,21.9,14.6$ and $12.6 \mathrm{~g} / \mathrm{m}^{2}$ and the obtained yield were 1636, 1372, 1171 and $950 \mathrm{~g} / \mathrm{m}^{2}$ at water regimes $(100,80,60$ and $40 \%)$ of maximum evapotranspiration, respectively. As shown in Figure (9), the coefficient of determination was (0.96) with slope (16.85) under controlled conditions. While under water stress treatments, the coefficient of determination was (0.97) with slope (14.25). Also, Table (3) shows that the SPAD values generally increased with increasing water stress. For the two seasons, SPAD values ranged from 30.1 to 41.4 and from 32.8 to 49.7 at three levels of nitrogen and zero water stress conditions. While at water stress treatments, these values ranged from 37.3 to 44.0 and from 40.0 to 54.3 , respectively. Coefficients of determination for the relationships between SPAD values and nitrogen levels under control and water stress conditions are shown in Figure (10). There are a high significant between SPAD values and 
nitrogen levels $\left(\mathrm{R}^{2}=0.99\right.$ and 0.99$)$. On the other hand, the values of the line slope were (7.05 and 5.15) and the intercepts were (23.95 and 33.37). These results are in agreement with Isabela et al .(2012) and AlMahmud et al. (2014). SPAD readings were well correlated with the nitrogen in leaves of potato $\left(\mathrm{R}^{2}=0.95\right)$ according to Vos and Bom (1993). Also, These results agree with findings by Lobos et al. (2003) who reported that SPAD readings were highly correlated with total chlorophyl $\left(\mathrm{R}^{2}=0.89\right)$. Also, these results agreed with Yuan et al. (2003) who showed that plant height, biomass amount, and tubers were increased by increasing the irrigation water at irrigation regimes (125, $100,75,50$ and $25 \%$ ) of evaporated water.

Table (3): Average dry biomass (kg/fed), nitrogen concentration (\%), $\mathrm{N}$ uptake (kg/fed) and SPAD value under control and water stress conditions at three nitrogen levels for two seasons.

\begin{tabular}{|c|c|c|c|c|c|c|c|c|c|}
\hline \multirow{2}{*}{$\begin{array}{c}\text { Measured } \\
\text { parameters }\end{array}$} & \multirow{2}{*}{ Treatments } & \multicolumn{4}{|c|}{ First season } & \multicolumn{4}{|c|}{ Second season } \\
\hline & & Min & Max & Mean & SD & Min & Max & Mean & SD \\
\hline \multirow{6}{*}{$\begin{array}{c}\text { DM } \\
\text { (kg/fed) }\end{array}$} & No-C & 233.9 & 333.3 & $267 \mathrm{~b}$ & 45 & 781 & 1254 & $912 \mathrm{~d}$ & 229 \\
\hline & N50-C & 250.3 & 555.7 & 435.3ab & 144 & 1080 & 1698 & 1366 & 295 \\
\hline & N100-C & 359.9 & 716.0 & $509.1 \mathrm{a}$ & 174 & 1808 & 2775 & $\mathrm{~cd}$ & 497 \\
\hline & N0-WS & 170 & 230 & $200.6 \mathrm{~b}$ & 77 & 660.9 & 880.9 & 2275 & 503 \\
\hline & N50- WS & 220.6 & 361.4 & $326.3 \mathrm{ab}$ & 70 & 920.0 & 1203 & $a b$ & 797 \\
\hline & N100-WS & 310.9 & 533.5 & $430 \mathrm{ab}$ & 32 & 1388 & 1983 & $\begin{array}{c}760 \mathrm{abc} \\
1104 \\
\mathrm{bc} \\
1738 \mathrm{a}\end{array}$ & 609 \\
\hline \multirow{6}{*}{$\mathbf{N}(\%)$} & No-C & 2.49 & 3.24 & $2.9 \mathrm{c}$ & 0.3 & 2.8 & 2.88 & $2.8 \mathrm{c}$ & 0.0 \\
\hline & N50. & 2.6 & 3.85 & $3.3 \mathrm{c}$ & 0.59 & 2.9 & 3.14 & $3 c$ & 0.1 \\
\hline & N100-C & 3.1 & 3.99 & $3.7 \mathrm{bc}$ & 0.33 & 3.18 & 4.06 & $3.6 \mathrm{~b}$ & 0.3 \\
\hline & No-WS & 2.99 & 3.19 & $3.1 \mathrm{ab}$ & 0.09 & 2.7 & 3.31 & $3 c$ & 0.2 \\
\hline & N50-WS & 3.28 & 3.68 & $3.6 \mathrm{ab}$ & 0.2 & 3.24 & 3.85 & $3.5 \mathrm{~b}$ & 0.3 \\
\hline & N100-WS & 3.45 & 3.95 & $3.9 \mathrm{a}$ & 0.14 & 3.85 & 4.64 & $4.1 \mathrm{a}$ & 0.3 \\
\hline \multirow{6}{*}{$\begin{array}{c}\text { N uptake } \\
\text { (kg/fed) }\end{array}$} & No-C & 5.82 & 10.79 & $7.74 \mathrm{~d}$ & 1.5 & 21.86 & 36.11 & $25.5 \mathrm{~d}$ & 5.9 \\
\hline & N50-C & 6.51 & 21.39 & $14.3 \mathrm{ab}$ & 3.09 & 31.32 & 53.31 & $40.9 \mathrm{~cd}$ & 10 \\
\hline & N100-C & 11.15 & 28.56 & $18.37 \mathrm{a}$ & 4.9 & 57.49 & 112.66 & $81.9 \mathrm{~b}$ & 14 \\
\hline & No-WS & 5.08 & 7.33 & $6.21 \mathrm{c}$ & 2.2 & 17.84 & 29.15 & $22.8 \mathrm{bc}$ & 16 \\
\hline & N50-WS & 7.23 & 13.29 & $11.74 b c$ & 2.2 & 29.83 & 46.34 & $38.6 \mathrm{bc}$ & 22 \\
\hline & N100- WS & 10.72 & 21.07 & $16.79 a b$ & 1.5 & 53.43 & 92.04 & $71.28 \mathrm{a}$ & 28 \\
\hline \multirow{6}{*}{$\begin{array}{c}\text { SPAD } \\
\text { value }\end{array}$} & No-C & 27.20 & 33.22 & $30.1 \mathrm{c}$ & 2.5 & 31.00 & 35.76 & $32.8 \mathrm{~d}$ & 2.1 \\
\hline & N50-C & 24.40 & 48.20 & $35.1 \mathrm{bc}$ & 9.9 & 36.49 & 40.86 & $39.2 \mathrm{c}$ & 2 \\
\hline & N100-C & 41.30 & 52.00 & $41.4 \mathrm{ab}$ & 4.9 & 42.59 & 51.53 & $49.7 \mathrm{~b}$ & 4.9 \\
\hline & No-WS & 36.52 & 38.10 & $42.2 \mathrm{a}$ & 4.6 & 2.88 & 52.79 & $40 \mathrm{c}$ & 1.3 \\
\hline & & 37.80 & 51.90 & $37.3 \mathrm{abc}$ & 0.64 & 38.26 & 41.27 & $45.8 \mathrm{~b}$ & 2 \\
\hline & N100-WS & 48.90 & 51.60 & $44.0 \mathrm{ab}$ & 6.36 & 44.83 & 53.43 & $54.3 \mathrm{a}$ & 2.5 \\
\hline
\end{tabular}

$\mathrm{DM}=$ dry matter, $\mathrm{N} \%=$ nitrogen concentration, $\mathrm{C}=$ control, $\mathrm{WS}=$ water stress 


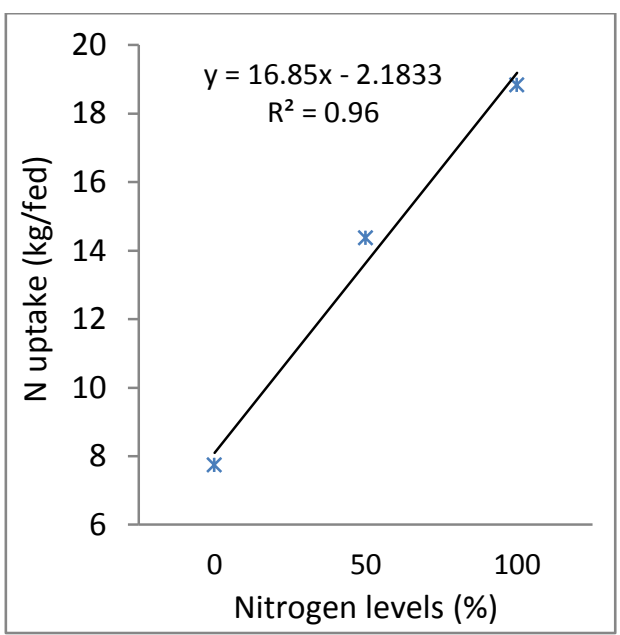

(a)

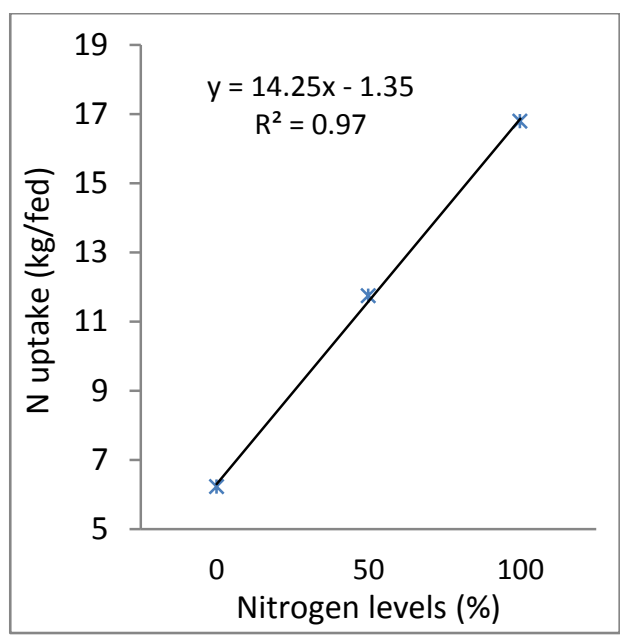

(b)

Fig.(9) The effect of water regimes levels and three nitrogen levels on nitrogen uptake(kg/fed) : (a) control and (b) water stress conditions.

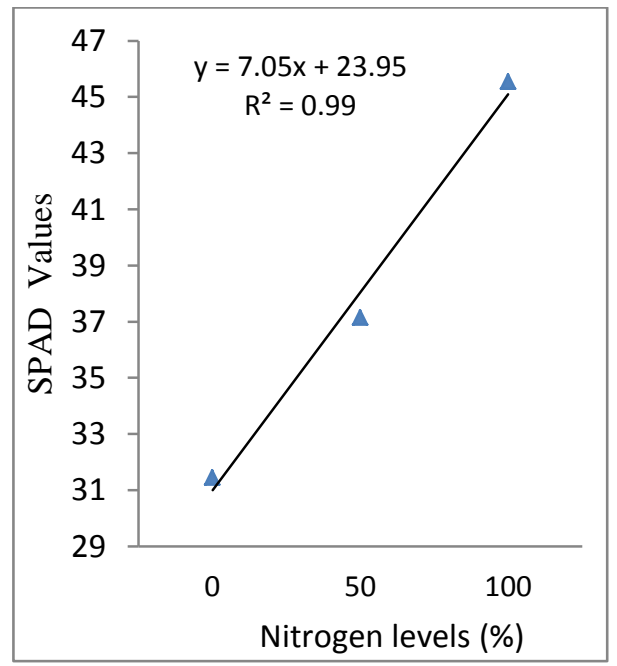

(a)

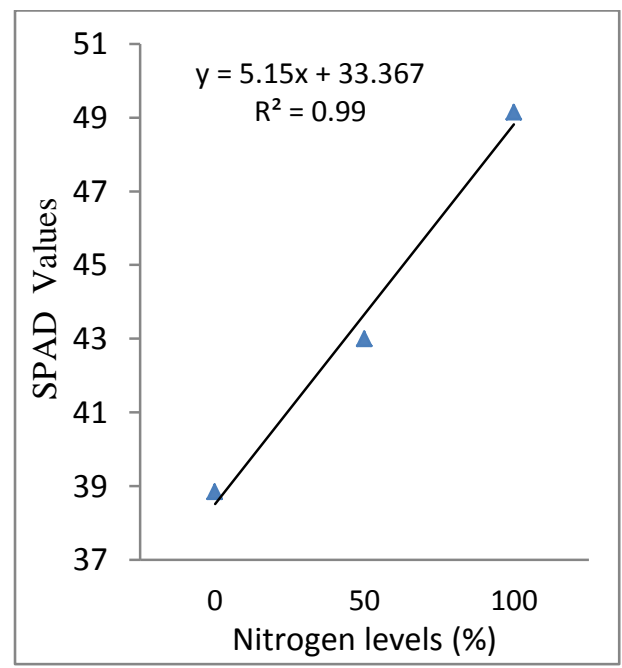

(b)

Fig. (10): Relationship between average SPAD values and nitrogen levels: (a) control and (b) water stress conditions.

\subsection{Relationships between Canopy Water Content with Dry Biomass,} Water Use Efficiency, Nitrogen Uptake and Soil Water Content

As shown in Figure (11), linear relationships between CWC with dry biomass $(\mathrm{kg} / \mathrm{fed})$ and water use efficency $\left(\mathrm{kg} / \mathrm{m}^{3}\right)$ were used. While, a quadratic equation was used to calculate the regression between CWC with nitrogen uptake (kg/fed) and SWC (\%). The slopes for relationship 
between CWC with dry biomass ( $\mathrm{kg} / \mathrm{fed})$ and water use efficency $\left(\mathrm{kg} / \mathrm{m}^{3}\right)$ were (25.86 and 0.854) and the intercepts were (-1815 and -63.68). On the other hand, coefficient of determination between CWC with dry biomass $(\mathrm{kg} / \mathrm{fed})$ water use efficency $\left(\mathrm{kg} / \mathrm{m}^{3}\right)$ were $\left(0.55^{* *}\right.$ and $\left.0.88^{* *}\right)$. These results coincide with Blum et al. (1982) who found that CWC decreased with increasing canopy temperature as a result of increased water stress. Also, CWC was directly correlation with nitrogen uptake $(\mathrm{kg} / \mathrm{fed})$ and SWC (\%). Coefficient of determination were $(0.64 * *$ and $\left.0.76^{* *}\right)$, respectively. The results showed that the best correlation with CWC was water use efficency $\left(\mathrm{kg} / \mathrm{m}^{3}\right)$ then $\mathrm{SWC}$ and the lowest correlation was nitrogen uptake then dry biomass.
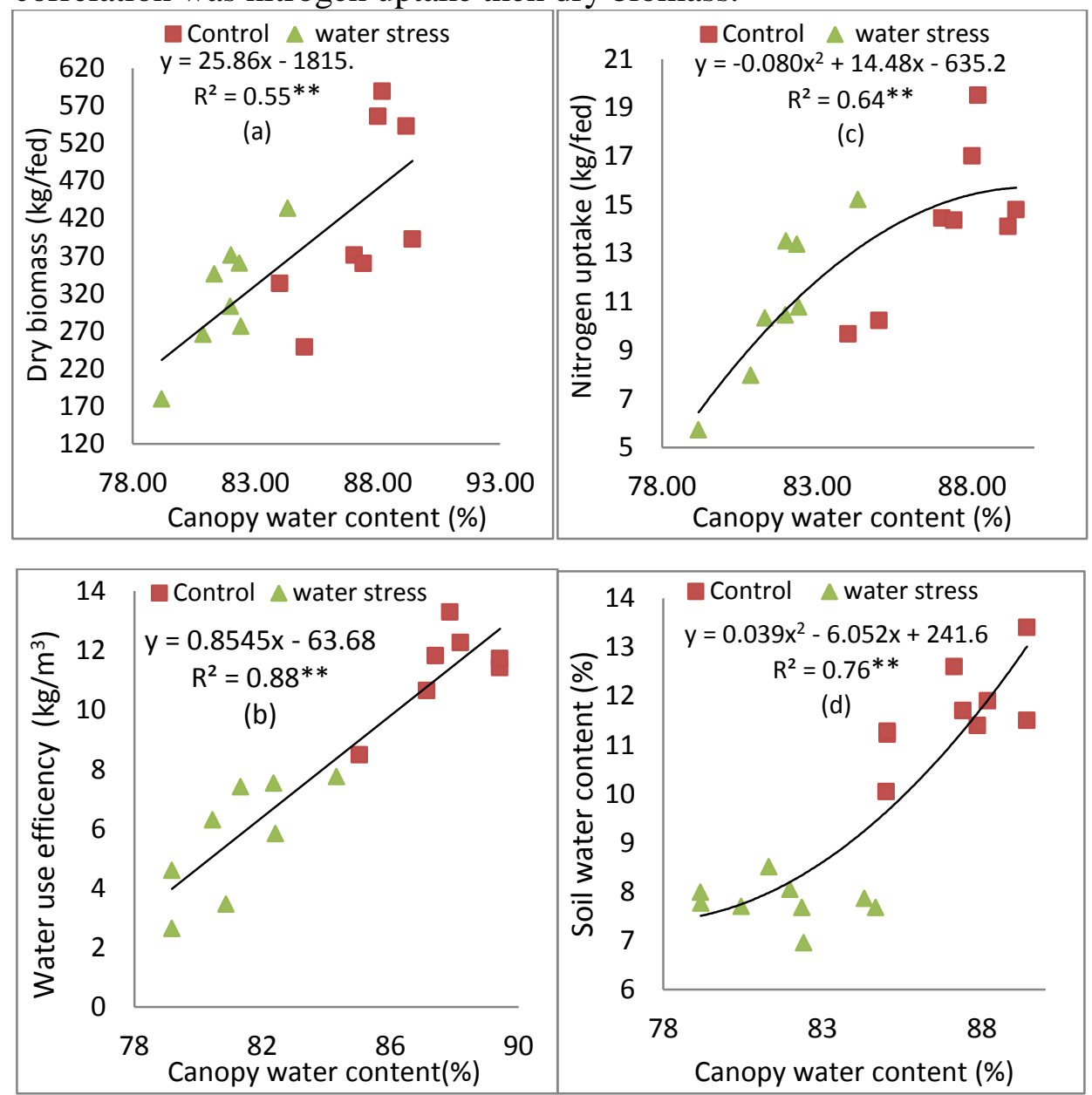

Fig. (11): Relationships between canopy water content with (a) dry biomass, (b) water use efficency, (c) nitrogen uptake and (d) Soil water content under control and water stress conditions. 
3.5 Relationships between Soil Water Content (\%) with Dry Biomass, Water Use Efficiency, Nitrogen Concentration and Nitrogen Uptake under Control and Water Stress Conditions

Linear relationships were used for calculating the regression coefficients between SWC and dry biomass ( $\mathrm{kg} / \mathrm{fed})$, nitrogen uptake $(\mathrm{kg} / \mathrm{fed})$ and water use efficency $\left(\mathrm{kg} / \mathrm{m}^{3}\right)$. While, a quadratic equation was used to calculate coefficient of determination between SWC and nitrogen concentration (\%) as shown in Figure (12).
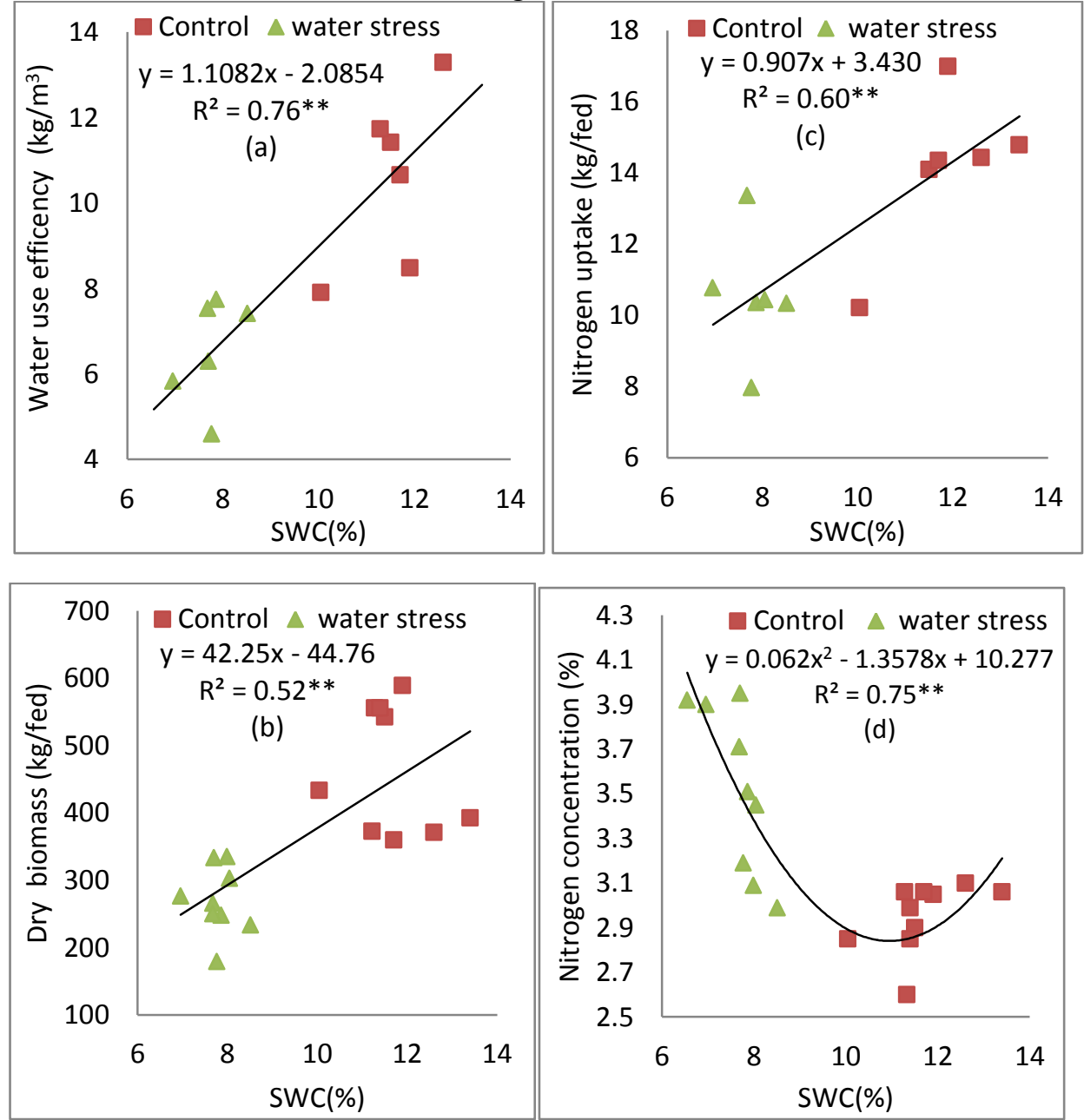

Fig. (12): Relationships between soil water content with (a) water use efficency, (b) dry biomass, (c) nitrogen uptake and (d) nitrogen concentration under control and water stress conditions. 
The slopes for relationships between SWC and water use efficency $\left(\mathrm{kg} / \mathrm{m}^{3}\right)$, dry biomass $(\mathrm{kg} / \mathrm{fed})$ and nitrogen uptake $(\mathrm{kg} / \mathrm{fed})$ were $(1.108$, 42.25 and 0.907$)$ and the intercepts were (-2.085, -44.76 and 3.430), respectively. On the other hand, coefficients of determination between SWC and water use efficency $\left(\mathrm{kg} / \mathrm{m}^{3}\right)$, nitrogen uptake $(\mathrm{kg} / \mathrm{fed})$ and dry biomass $(\mathrm{kg} / \mathrm{fed})$ were $\left(0.76^{* *}, 0.60^{* *}\right.$ and $\left.0.52^{* *}\right)$, respectively. Also, SWC was high directly correlation with nitrogen concentration (\%) and coefficient of determination was $0.75^{* *}$. The best correlation with SWC was water use efficency then nitrogen content and the lowest correlation was nitrogen uptake then dry biomass.

\subsection{Relationships between SPAD Values and nitrogen uptake (kg/fed) under control and water stress conditions}

In Figure (13), the best fit relationship between SPAD values and nitrogen uptake was found as a linear relationship with coefficient of determination 0.99 for both the zero and water stress conditions. In general, SPAD values were higher for stress more than zero level at the same amounts of applied nitrogen.

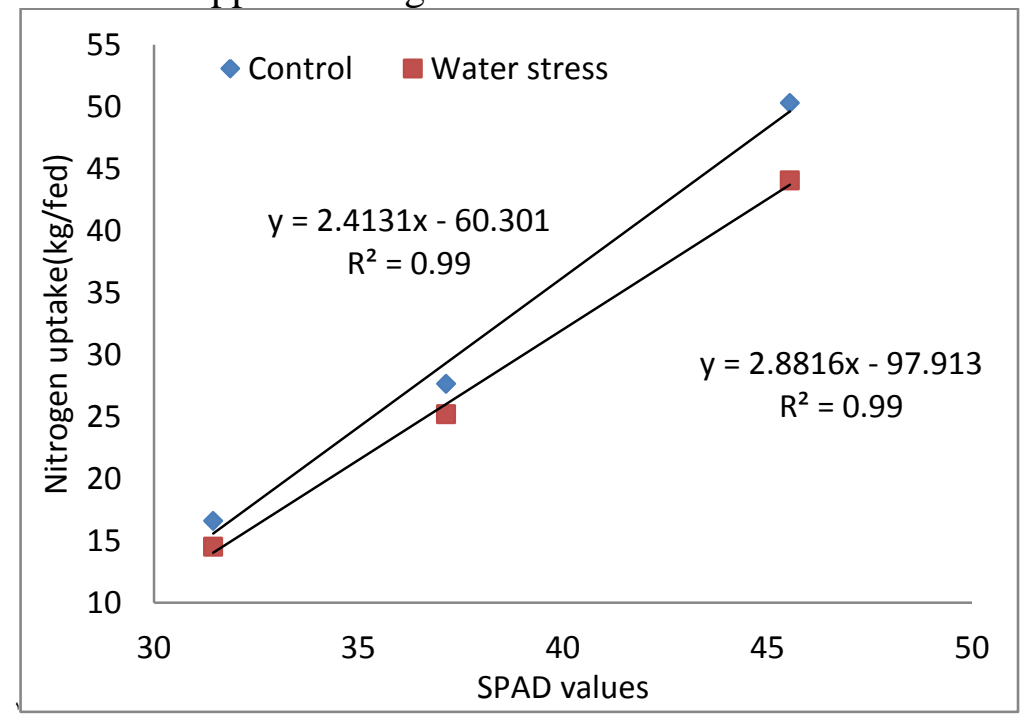

Fig. (13): Relationship between average SPAD values and nitrogen uptake: (a) control and (b) water stress conditions.

On the other hand, the slopes were 2.413 and 2.881 under controlled and water stressed. For these reasons, it's recommended that providing the plants with the optimum amount of water would increase the healthy 
conditions of plants (the yield) as the nitrogen uptake and SPAD value increase. These results agreed with Rodriguez et al (2000) and Uddling et al. (2007) who indicated that SPAD values were positively correlated with chlorophyll concentration $\left(\mathrm{R}^{2}=0.79\right.$ and 0.58$)$ for wheat and potato crops.

\section{CONCLUSIONS}

In conclusions, there are obvious effects of water stress on canopy water content, soil water content, yield, water use efficency, SPAD values and nitrogen uptake. Nitrogen uptake and water use efficency were higher in the zero stress level more than at the water stress. In contrast, SPAD values were the highest in water stress. The percentage of irrigation water saved was $11.47 \%$ for water stress conditions and the highest yield reduction was at N0 then $\mathrm{N} 100$ and the lowest reduction was at N50 compared with the zero stress level. It can be concluded that nitrogen uptake, and yield prediction of potato crop can be detected using potato canopy water content and nitrogen concentration in different levels of irrigation water and nitrogen.

\section{REFERENCES}

Akhter, M., M. Ali, Z. Haider, A. Mahmoud and U. Saleem.(2017). Comparison of Yield and Water Productivity of Rice (Oryza sativa L.) Hybrids in Response to Transplanting Dates and Crop Maturity Durations in Irrigated Environment. Irrigat Drainage Sys Eng, Volume 6, Issue 1, DOI: 10.4172/2168-9768.1000180

Allen, R. G., L. S. Pereira, D. Raes, and M. Smith.(1998). Crop evapotranspiration-guidelines for computing crop water requirements. FAO Irrigation and drainage paper 56. Food and Agriculture Organization, Rome.

Al-Mahmud, A., M. Hossain, M. Bazzaz, S. A. Khan, A. Hossain, and M. S. Kadian.(2014). Tuber Yield, Tuber Quality and Plant Water Status of Potato under Drought and Well Watered Condition.Global Journals Inc. (USA).,14(10) :2249-4626.

Bailey, R.(1990). Irrigation crops and their management. Farming Bress (ed). United Kingdom. (C.F. Computer Search). 
Beirne, D.O. and J. C. Cassidy.(1990). Effect of nitrogen fertilizer on yield, dry matter content and flouriness of potatoes. J. Sci. of Food and Agric., 52(3): 351-363.

Blum, A., J. Mayer and G. Gozlan.(1982). Infrared thermal sensing of plant canopies as a screening technique for dehydration avoidance in wheat. Field Crop Res. 5, 137- 146.

Costa, L. D., D. D. Vedove and R. Giovanardi.(1997). Yield, water use efficiency and nitrogen uptake in potato: influence of draught stress. Potato research 40: 19-34

Demotes, S., R. Boumaza, S. Meyer, and Z. G. Cerovic.(2008). Indicators of nitrogen status for ornamental woody plants based on optical measurements of leaf epidermal polyphenol and chlorophyll contents. Sci. Hort. 115: 377-385.

El-mokh, F., K. Nagaz, M. M. Masmoudia, and N. B. Mechlia .(2014).Effects of surface and subsurface drip irrigation regimes with saline water on yield and water use efficiency of potato in arid conditions of Tunisia.Journal of Agriculture and Environment for International Development - JAEID , 108 (2): 227 - 246

El-mokh, F., K. Nagaz, M. M. Masmoudia, and N. B. Mechlia .(2015).Yield and Water Productivity of Drip-Irrigated Potato under Different Nitrogen Levels and Irrigation Regime with Saline Water in Arid Tunisia. American Journal of Plant Sciences, 6 , 501-510. Published Online March 2015 in SciRes. http://www.scirp.org/journal/ajps, http://dx.doi.org/10.4236/ajps.2015.64054

FAO.(2011). Agricultural data FAOSTAT. Food and Agriculture Organization of the United Nations. Rome, Italy.

Gianquinto, G., J. P. Goffart, M. Olivier, G. Guarda, M. Colauzzi, L. Dalla Costa, G. Delle Vedove, J. Vos, and D. K. MacKerron. (2004). The use of hand-held chlorophyll meters as a tool to assess 
the nitrogen status and to guide nitrogen fertilization of potato crop. Potato Res 47:35-80

Ibrahim, M. M., M. H. Ramadan, N. G. Abdelfatah.(2015). Evaluating farm irrigation water mangement models for wheat and corn crops. Misr J. Ag. Eng., 32(2): 687-712.

Isabela, G. O., G. Morar, and M. Ianoşi.(2012). Monitoring The vegetation status of potato. Agricultura - Ştiinţă şi practică. nr. 1- 2 (81-82).

Johnson, L. F.(2001). Nitrogen influence on fresh-leaf NIR spectra. remote sensing of environment, 78, pp. 314-320.

Juzl, L. M.(1993). Nitrogen nutrition in relation to the yield and nitrate content in tubers of very early potatoes. Rostilinna Vyroba, 39(11): 987-993(C.F. Computer Search).

Kassem, A. M. and A. M. AL-Moshileh.(2005). Effect of on-farm irrigation systems and water regimes on potato yield and water use efficiency. Misr J. Ag .Eng., 22(2) : 679-698.

Konica, M. O.(2012). Chlorophyll Meter SPAD-502Plus - A lightweight handheld meter for measuring the chlorophyll content of leaves without causing damage to plants. URL: http://www.konicaminolta.com/instruments/download/catalog/color /pdf/spad502plus_e1.pdf (as of: Apr/13).

Kumar, D. and J. S. Minhas.(1999). Effect of water stress on photosynthesis, productivity and water status in potato. J. of Indian Potato Association, 26(1/2): 7-10.

Lemaire, G. and F. Gastal.(1997). N uptake and distribution in plant canopies. In: Lemaire G. (Ed.), Diagnosis of the Nitrogen Status in Crops. Springer-Verlag 3-41.

Lobos, G. A., I. Matus, A. Rodriguez, S. Romero-Bravo, J. L. Araus, A. D. Pozo, A. C. Madeira, A. Ferreira, A. D. Varennes and M. I. Vieira.(2003). SPAD meter versus tristimulus colorimeter to 
estimate chlorophyll content and leaf color in sweet pepper. Comm. Soil Sci. Plant Anal. 34(17-18): 2461-2470.

Ojala, J. C., J. C. Stark, and G. E. Kleinkopf.(1990). Influence of irrigation and nitrogen management on potato yield and quality. American Potato J., 67: 29-43.

Onder, S., M. E. Caliskan, D. Onder, and S. Caliskan.(2005). Different irrigated methods and water stress effects on potato yield and yield components. Agric. Water Management, 73: 73-86.

Rodriguez, I, R., G. L. Miller.(2000). Using a Chlorophyll Meter to determine the Chlorophyll Concentration, Nitrogen Concentration, and Visual Quality of St. Augustine grass. Hort science 35(4):751754.

Shock, C. C.(2004). Efficiency irrigation scheduling. Malheur Experiment Station, Oregon State University, Oregon, USA.

Smith, M.(1992). CROPWAT A computer program for irrigation planning and management. Irrigation and Drainage Paper No. 46, FAO, Rome, Italy. 125 P.

Uddling, J., J. G. Alfredsson, K. Piikki and H. Pleijel.(2007). Evaluating the relationship between leaf chlorophyll concentration and SPAD-502 chlorophyll meter readings. Photosynth Res 91:3746

Vos, J. and M. Bom.(1993). Hand-held chlorophyll meter: a promising tool to assess the nitrogen status of potato foliage. Potato Res. 36: 301-308.

World weather online.(2015). Madinat As Sadat, Egypt Weather Forecast. Available at: (http://www.worldweatheronline.com/madinat-as-sadat-weather/albuhayrah/eg.aspx) Accessed on May 2016.

Yuan, B., S. Nishiyama, and Y. Kang.(2003). Effect of drip irrigation regimes on the growth and yield of drip- irrigated potato. Agric Water Manage ., 63 (31) : 153-167 


\section{الملخص العربى}

\section{تاثير الاجهاد المائي علي حالة التيتروجين بالاضافة الي كفاءة استخدام المياه لمحصول البطاطس تحث نظام الري بالتثقيط الته}

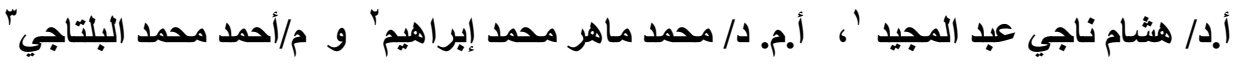

نظر الان اتجاه الدولة الحالي هو التوسع الافقي في الاراضي الجديدة وحيث ان هذه الار اضي تحتاج لكميات كبيرة من المياه والأسمدة النيتروجينية لاستصلاحها لذلك يعتبر معدل ونوقيت اضافة المياه مع معدلات مختلفة من النيتروجين من العوامل الهامة في تحسين محصول درنات البطاطس وجودتها. تهدف هذه الدراسة الي توضيح تاثير الاجهاد المائي علي المحتوي المائي بالمجموع الخضري و الوزن الجاف للمجموع الخضري ورطوبة التربة و انتاجية المياة وكذلك النيتروجين الممتص بالنبات. لتحقيق اهداف الدراسة تم اجراء تجربتان في مزرعة معهد ورهو البحوث و الدر اسات البيئية بجامعة مدينة السادات. اجريت التجربة الاولي في فصل الثتاء حيث

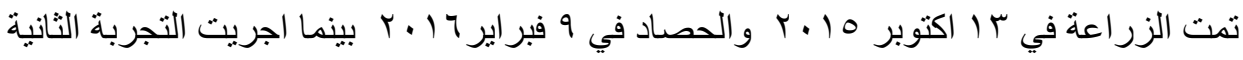

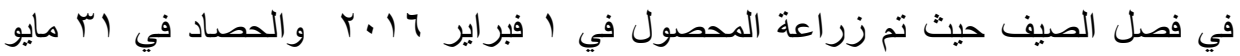

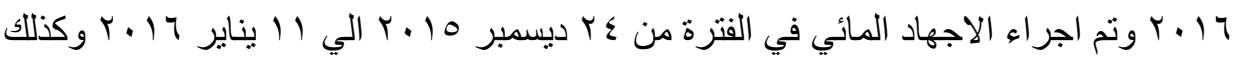

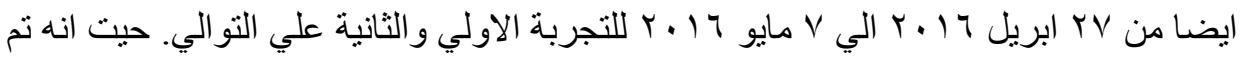
اخذ جميع القراءات في فترات الاجهاد المختلفة وتمت عملية جدولة مياه الري باستخدام برنامج

علي اساس بيانات يومية. (CROPWAT ver. 8.0)

أوضحت النتائج ان قراءات جهاز قياس الكلورفيل كانت عالية تحت ظروف الاجهاد المائي مقارنة بالقراءات تحت الظروف المثلي. حيث انه يوجد علاقة بين قراءات جهاز قياس الكلورفيل تحت تاثير مستويات النيتروجين المختلفة وكان معامل التحديد تحت ظروف باءت الري

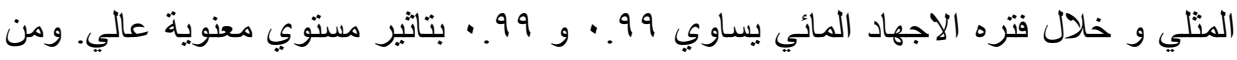
جانب اخر وجد ان النيتروجين الممتص يزداد في الظروف المثلي ويقل تحت ناثير الاجهاد

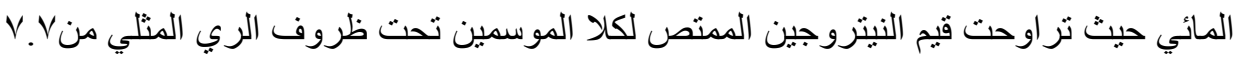

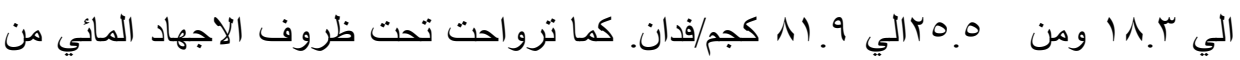

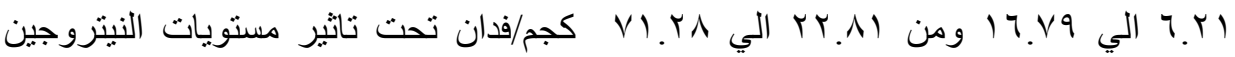
المختلفة علي التوالي. ومن جانب اخر وجدت علاقة قوية بين قراءات جهاز الكلورفيل و النيتروجين الممتص بمعامل ارتباط 99. . • و 99. . • بتاثير معنوية عالي جدا.

\footnotetext{
(' (') أستاذ و أستاذ مساعد بقسم الهندسة الزراعية ـ كلية الزراعة - جامعة المنصورة

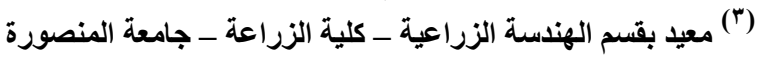




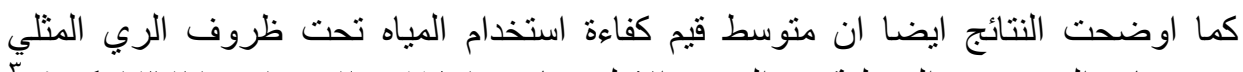

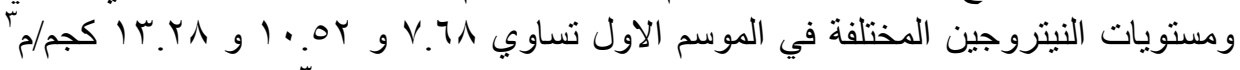

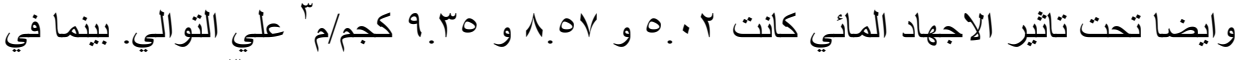

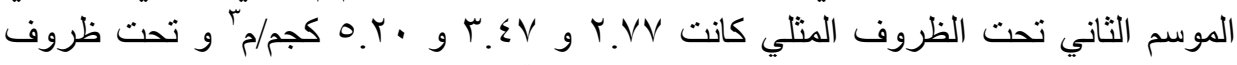

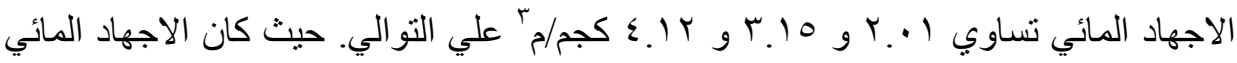

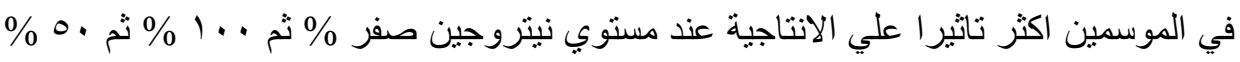

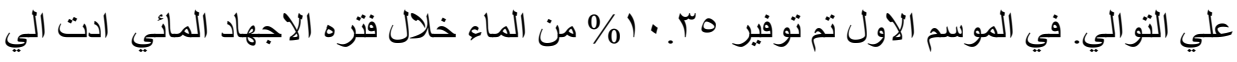

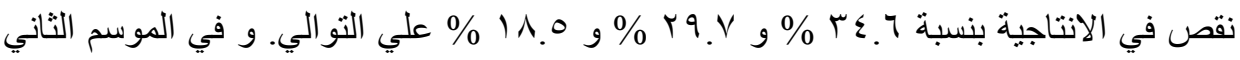

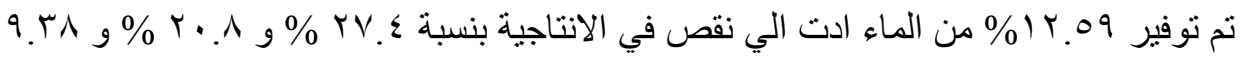

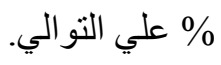

لذللك تبين الدر اسة بأنه يمكن استخدام المحتوي المائي للمجموع الخضري بمحصول البطاطس في التنبؤ بحالة النيتروجين للنبات وكذللك الانتاجية. 